\title{
Pemberian Ekstrak Daun Gandarusa (Justicia gendarussa Burm. f.) Menurunkan Kadar F2-isoprostan Urin Tikus Wistar (Rattus norvegicus) Jantan yang Diinduksi Latihan Fisik Berlebih
}

\author{
${ }^{1}$ DG Ika Akpriyanti, ${ }^{2}$ Wimpie Pangkahila, ${ }^{3}$ IGM Aman
}

\author{
${ }^{1}$ Program Pascasarjana Anti-Aging Medicine \\ ${ }^{2}$ Departemen Andrologi dan Seksologi \\ ${ }^{3}$ Departemen Farmakologi \\ Fakultas Kedokteran Universitas Udayana Denpasar \\ E-mail: ika_geg@yahoo.co.id
}

\begin{abstract}
Excessive physical activity increases the consumption of oxygen which can result in increased levels of reactive oxygen species (ROS) causing oxidative stress characterized by the elevation of F2-isoprostane as a byproduct of lipid peroxidation. Willow (Justicia gendarussa Burm. $f$.) has an antioxidant activity that is able to inhibit and break the chain reaction of free radicals and prevent lipid peroxidation. This study was aimed to prove that willow leaf extract could inhibit the elevation of F2-isoprostane levels in male Wistar rats (Rattus norvegicus) urin induced by excessive physical training. This was a true experimental study using 16 male Wistar rats (Rattus norvegicus), aged 2-3 months, weighing 180-200 g as subjects. The control group (P0) was treated with a placebo and excessive physical training, and the treatment group (P1) was treated with the willow leaf extract of $200 \mathrm{mg} / \mathrm{rat} / \mathrm{day}$ and excessive physical training. Before and after 14 days of treatment, the urine samples were collected and their levels of F2-isoprostane 8 -isoPGF2 $\alpha$ were examined by using enzyme immunoassay kit (EIA). The results showed that the mean level of F2-isoprostane in the control group (P0) before treatment (pretest) was $5.20 \pm 0.483 \mathrm{ng} / \mathrm{mL}$ while in the treatment group (P1) was $5.46 \pm 0.655 \mathrm{ng} / \mathrm{mL}(P>0.05)$. On the other hand, after treatment for 7 days (post-test), the mean level of F2-isoprostane in the control group (P0) was $5.34 \pm 0.476 \mathrm{ng} / \mathrm{mL}$ and in the treatment group (P1) was $3.61 \pm 0.389 \mathrm{ng} / \mathrm{mL}(P<0.01)$. Conclusion: The extract of willow (Justicia gendarussa Burm. f.) leaf could inhibit the elevation of F2-isoprostane levels in male Wistar rats (Rattus norvegicus) urin induced by excessive physical training.
\end{abstract}

Keywords: willow leaf, F2-isoprostane, excessive physical training

\begin{abstract}
Abstrak: Aktivitas fisik berlebih akan meningkatkan komsumsi oksigen yang dapat mengakibatkan peningkatan kadar reactive oxygen species (ROS) sehingga menyebabkan stres oksidatif yang ditandai dengan meningkatnya F2-isoprostan sebagai salah satu produk peroksidasi lipid. Tanaman gandarusa (Justicia gendarussa Burm. f.) mengandung antioksidan yang dapat mencegah reaksi peroksidasi lipid. Penelitian ini bertujuan untuk membuktikan bahwa pemberian ekstrak daun gandarusa dapat menurunkan kadar F2-isoprostan urin tikus Wistar (Rattus norvegicus) jantan yang diinduksi latihan fisik berlebih. Jenis penelitian ialah eksperimental dengan subjek 16 ekor tikus (Rattus norvegicus), galur Wistar, sehat, berumur 6 bulan, berat badan 180-200 gr, dengan kadar F2-isoprostan >2ng/mL. Kelompok kontrol (P0) diberikan pelatihan fisik berlebih dan plasebo aquadest $2 \mathrm{ml}$ sedangkan kelompok perlakuan (P1) diberikan pelatihan fisik berlebih dan ekstrak daun gandarusa dosis $200 \mathrm{mg} / \mathrm{ekor} / \mathrm{hari}$. Sebelum dan setelah 14 hari perlakuan, sampel urin ditampung dan diperiksa kadar F2isoprostan menggunakan 8-isoPGF $2_{\alpha}$ enzyme immunoassay kit (EIA) dari assay design untuk data pretest dan post-test. Hasil penelitian menunjukkan rerata kadar F2-isoprostan pada

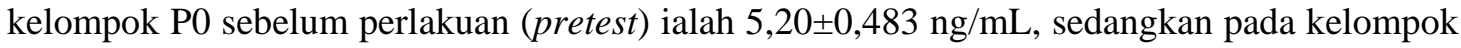


P1 ialah 5,46 $\pm 0,655 \mathrm{ng} / \mathrm{mL}(P>0,05)$. Setelah perlakuan selama 14 hari (post-test), rerata kadar F2-isoprostan pada kelompok P0 ialah 5,34 $\pm 0,476 \mathrm{ng} / \mathrm{mL}$ dan pada kelompok P1 ialah $3,61 \pm 0,389 \mathrm{ng} / \mathrm{mL}(P<0,01)$. Simpulan: Ekstrak daun gandarusa (Justicia gendarussa burm. f.) dapat menurunkan kadar F2-isoprostan urin tikus Wistar (Rattus norvegicus) jantan yang diinduksi latihan fisik berlebih.

Kata kunci: daun gandarusa, F2-isoprostan, pelatihan fisik berlebih

Pelatihan fisik berlebih adalah volume latihan yang terlalu banyak, intensitas pelatihan yang terlalu tinggi, durasi pelatihan yang terlalu panjang, atau frekuensi pelatihan yang terlalu sering yang menghasilkan penurunan kinerja jangka panjang, atau bahkan ditandai oleh penurunan kinerja yang spesifik. ${ }^{1,2}$ Dilaporkan bahwa pelatihan fisik berlebih dapat meningkatkan reactive oxygen species (ROS) yang merupakan faktor utama terjadinya stres oksidatif. ${ }^{3}$ Stres oksidatif dapat merusak molekul biologis yang terdapat di dalam tubuh seperti lipid, protein, dan deoxyribonucleic acid (DNA). Jika hal ini terjadi dalam waktu berkelanjutan, maka akan terjadi akumulasi hasil kerusakan oksidatif di dalam sel dan jaringan sehingga menyebabkan jaringan tersebut kehilangan fungsinya. ${ }^{4}$ Stres oksidatif dapat terjadi secara lokal, seperti pada penyakit artritis dan aterosklerosis, maupun secara sistemik, seperti pada systemic lupus erythematosus dan diabetes. ${ }^{5}$ Tingginya kadar radikal bebas dalam tubuh tanpa disertai peningkatan antioksidan menyebabkan faktor-faktor inflamasi seperti leukosit PMN, makrofag, dan peroksisom menjadi terstimulasi kemudian mengakibatkan berbagai macam penyakit inflamasi seperti sirosis, emfisema, dan kanker yang berhubungan kerusakan oksidatif. ${ }^{6}$

Kondisi stres oksidatif dapat dideteksi dengan menggunakan indikator F2isoprostan (8-iso-PGF2 $\alpha$ ) yang merupakan hasil peroksidase lipid membran sel di dalam tubuh akibat radikal bebas. ${ }^{7}$ F2isoprostan ialah komponen prostaglandinlike yang terbentuk dari katalisis peroksidasi radikal bebas dari asam lemak esensial (primarily arachidonic acid) tanpa perintah atau aksi langsung dari enzim cyclooxygenase (COX). F2-isoprostan ialah eicosanoid non klasikal dan memiliki aktivitas biologikal yang poten sebagai mediator inflamasi yang menimbulkan persepsi nyeri. F2-isoprostan merupakan indikator yang akurat dari peroksidasi lipid baik pada manusia maupun hewan dalam konteks terjadinya stres oksidatif. ${ }^{8}$

Upaya yang banyak dilakukan untuk mencegah proses penuaan akibat radikal bebas ialah dengan penggunaan antioksidan yang dapat mencegah teroksidasinya molekul lain oleh radikal bebas dengan cara mendonorkan elektronnya sehingga radikal bebas menjadi stabil. Antioksidan dapat berasal dari dalam tubuh (endogen) maupun dari luar tubuh (eksogen), misalnya dari diet dan suplementasi makanan. ${ }^{9}$ Konsumsi makanan yang mengandung antioksidan maupun suplementasi antioksidan diperlukan oleh tubuh untuk mereduksi kerusakan oksidatif. $^{10,11}$

Tanaman gandarusa

(Justicia gendarussa Burm. f.) merupakan salah satu tanaman obat yang tumbuh liar di hutan dan sudah lama dimanfaatkan sebagai tanaman obat. ${ }^{12}$ Esktrak daun gandarusa mengandung berbagai macam senyawa aktif yang berpotensi sebagai antioksidan seperti flavonoid, saponin, tannin dan fenol. Analisis fitokimia yang dilakukan di Laboratorium Teknologi Pertanian Universitas Udayana (2016) menunjukkan bahwa ekstrak air daun gandarusa mengandung flavonoid yang terdiri dari fenol, tannin, dan saponin dengan aktivitas antioksidan sebesar 257,26 ppm GAEAC dan inhibition concentration 50 (IC50) sebesar $4,15 \mathrm{mg} / \mathrm{ml}$.

Mekanisme antioksidan ekstrak daun gandarusa dalam mencegah kerusakan oksidatif akibat pelatihan fisik berlebih ialah karena kemampuannya untuk menstabilkan 
membran sel. Membran sel yang stabil dibutuhkan oleh lisosom untuk mencegah pelepasan respon inflamasi, yang selanjutnya dapat memicu pembentukan ROS. ${ }^{13}$ F2isoprostan terlibat dalam inflamasi akut maupun inflamasi kronik, dengan PGF $2 \alpha$ sebagai perantara terjadinya inflamasi akibat radikal bebas yang kemudian menginisiasi stres oksidatif. $^{14}$

\section{METODE PENELITIAN}

Penelitian ini bertujuan untuk membuktikan bahwa pemberian ekstrak daun gandarusa (Justicia gendarussa Burm. f.) dapat menurunkan kadar F2-Isoprostan urin tikus wistar jantan yang diinduksi pelatihan fisik berlebih. Jenis penelitian ialah eksperimental dengan randomized pretest-posttest control group design.

Subjek penelitian ini ialah 16 ekor tikus (Rattus norvegicus), galur Wistar, sehat, berumur 6 bulan, berat badan 180200 gr, dengan kadar F2-isoprostan $>2 \mathrm{ng} / \mathrm{mL}$ yang terbagi menjadi 2 (dua) kelompok masing-masing berjumlah 8 ekor tikus. Kelompok pertama ialah kelompok kontrol (P0) yang diberikan pelatihan fisik berlebih dan plasebo berupa aquadest $2 \mathrm{ml}$ selama 14 hari, dan kelompok kedua ialah kelompok perlakuan (P1) yang diberikan pelatihan fisik berlebih dan ekstrak daun gandarusa (Justicia gendarussa Burm. f.) dosis $200 \mathrm{mg} / \mathrm{ekor} /$ hari. Perlakuan dalam penelitian ini berlangsung selama 14 hari. Sebelum dan setelah perlakuan, semua tikus pada kedua kelompok diambil urin dengan menggunakan kandang koleksi urin untuk diperiksa kadar F2-isoprostan yang selanjutnya diuji dengan menggunakan metode indirect ELISA.

\section{HASIL DAN BAHASAN}

Hasil penelitian menunjukkan bahwa rerata kadar F2-isoprostan pada kelompok kontrol (P0) sebelum diberikan perlakuan (pretest) ialah 5,20 $\pm 0,483 \mathrm{ng} / \mathrm{mL}$, sedangkan pada kelompok perlakuan (P1) sebelum diberikan perlakuan (pretest) ialah $5,46 \pm 0,655 \mathrm{ng} / \mathrm{mL}(P>0,05)$. Setelah perlakuan selama 14 hari (posttest), rerata kadar F2-isoprostan pada kelompok kontrol
(P0) ialah 5,34 $\pm 0,476 \mathrm{ng} / \mathrm{mL}$, sedangkan pada kelompok perlakuan (P1) ialah 3,61 $\pm 0,389 \mathrm{ng} / \mathrm{mL}(P<0,01)$ (Tabel 1, Gambar 1).

\section{Rerata Kadar F2-Isoprostan}

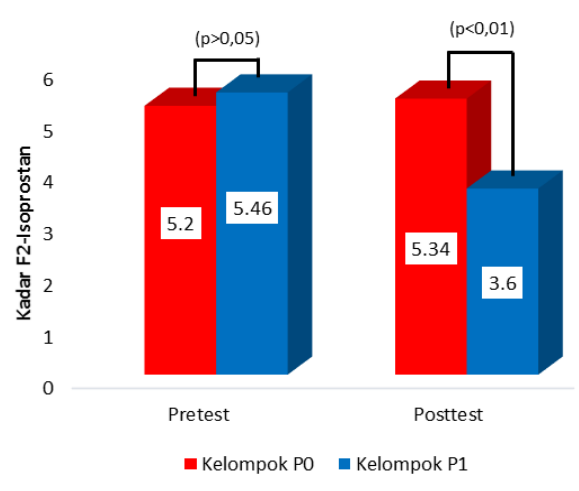

Gambar 1. Perbandingan rerata kadar F2isoprostan setiap kelompok

Hasil analisis efek perlakuan menunjukkan bahwa pada kelompok kontrol (P0) terjadi peningkatan kadar F2isoprostan dari $5,20 \pm 0,483 \mathrm{ng} / \mathrm{mL}$ menjadi $5,34 \pm 0,476 \mathrm{ng} / \mathrm{mL}$ setelah 14 hari diberikan perlakuan berupa pelatihan fisik berlebih dan aquadest $2 \mathrm{ml}$, walaupun secara statistik peningkatan ini tidak berbeda bermakna $(P$ $>$ 0,05). Pada kelompok perlakuan (P1) terjadi penurunan kadar F2-isoprostan yang bermakna dari $5,46 \pm 0,655 \mathrm{ng} / \mathrm{mL}$ menjadi 3,61 $\pm 0,389$ setelah 4 minggu diberikan perlakuan berupa pelatihan fisik berlebih dan ekstrak daun gandarusa (Justicia gendarussa Burm. f.) $(P<0,01)$ (Tabel 2).

Dalam penelitian ini, pelatihan fisik berlebih diberikan dengan cara perenangan sampai subjek penelitian hampir tenggelam untuk mendapatkan kondisi stres oksidatif. Aktivitas fisik berlebih dapat meningkatkan konsumsi oksigen sampai 100-200 kali lipat. Umumnya $2-5 \%$ dari oksigen yang dipakai dalam proses metabolisme akan menjadi ion superoksid, sehingga saat aktivitas fisik berat terjadi peningkatan produksi radikal bebas yang akan memicu terjadinya stres oksidatif dan dapat merusak semua sel di dalam tubuh. ${ }^{15}$ 
Tabel 1. Komparasi kadar F2-isoprostan antar kelompok

\begin{tabular}{llcccc}
\hline Pemeriksaan & \multicolumn{1}{c}{ Kelompok } & N & Rerata \pm SB & $\boldsymbol{t}$ & $\boldsymbol{P}$ \\
\hline \multirow{2}{*}{ Pretest } & Kontrol (P0) & 8 & $5,20 \pm 0,483$ & \multirow{2}{*}{0,899} & \multirow{2}{*}{0,384} \\
& Perlakuan (P1) & 8 & $5,46 \pm 0,655$ & & \\
Posttest & Kontrol (P0) & 8 & $5,34 \pm 0,476$ & \multirow{2}{*}{7,987} & 0,000 \\
& Perlakuan (P1) & 8 & $3,61 \pm 0,389$ & & \\
\hline
\end{tabular}

$\mathrm{N}=$ jumlah sampel; $\mathrm{SB}=$ simpangan baku; $t=t$-hitung; $P=$ signifikansi

Tabel 2. Analisis pre-post kadar F2-isoprostan pada setiap kelompok

\begin{tabular}{llcccc}
\hline \multicolumn{1}{c}{ Kelompok } & n & Rerata pretest & Rerata posttest & $\boldsymbol{t}$ & $\boldsymbol{P}$ \\
\hline Kontrol (P0) & 8 & $5,20 \pm 0,483$ & $5,34 \pm 0,476$ & $-0,676$ & 0,521 \\
Perlakuan (P1) & 8 & $5,46 \pm 0,655$ & $3,61 \pm 0,389$ & 7,351 & 0,000 \\
\hline
\end{tabular}

Selain itu, ketika melakukan aktivitas fisik yang cukup berat terjadilah peristiwa menyerupai fenomena iskemia-reperfusi, dimana peningkatan penyediaan oksigen (oxygen supply) sering kali tidak mampu memenuhi kebutuhan oksigen (oxygen demand). Fenomena ini disebut sebagai fase iskemia. Peningkatan penyediaan oksigen yang tinggi justru akan meningkatkan pembentukan radikal bebas oksigen bahkan bisa mencapai 10x lipat (fenomena ini disebut fase reperfusi). Beberapa penelitian telah membuktikan bahwa aktivitas fisik yg berat dapat menyebabkan stres oksidatif dengan produksi radikal bebas oksigen meningkat secara bermakna. ${ }^{16}$ Penelitian telah membuktikan bahwa aktivitas fisik yang berat dapat menyebabkan stres oksidatif dan trauma otot. ${ }^{17}$

Kondisi stres oksidatif dapat dideteksi dengan menggunakan indikator F2isoprostan (8-iso-PGF2 $\alpha$ ) yang merupakan hasil dari peroksidase lipid membran sel di dalam tubuh akibat radikal bebas. ${ }^{7}$ (Hanak, 2010). F2-isoprostan adalah komponen prostaglandin-like yang terbentuk dari katalisis peroksidasi radikal bebas dari asam lemak esensial (primarily arachidonic acid) tanpa perintah atau aksi langsung dari enzim cyclooxygenase (COX). F2isoprostan merupakan eicosanoid non klasikal dan memiliki aktivitas biologikal yang poten sebagai mediator inflamasi yang menimbulkan persepsi nyeri. F2-isoprostan merupakan indikator yang akurat dari peroksidasi lipid baik pada manusia maupun hewan dalam konteks terjadinya stress oksidatif karena kadar F2-isoprostan meningkat pada beberapa keadaan yang berkaitan dengan cedera oksidatif. ${ }^{8}$ Kadar F2-isoprostan normal pada urin tikus jantan dewasa ialah $<2 \mathrm{ng} / \mathrm{mL}$ sehingga jika kadar F2-isoprostan urin $>2 \mathrm{ng} / \mathrm{mL}$ dapat diasumsikan terjadi stres oksidatif di dalam tubuh tikus tersebut.

Pada penelitian ini, sebelum perlakuan dimulai seluruh kelompok tikus diberikan pelatihan fisik berlebih selama 7 hari untuk menyebabkan kondisi stres oksidatif. Hasil penelitian menunjukkan bahwa setelah 7 hari pelatihan fisik berlebih dan sebelum perlakuan selama 14 hari (pretest), kadar F2-isoprostan pada kedua kelompok >2 ng/mL. Peningkatan kadar F2-isoprostan yang terjadi pada keadaan pelatihan fisik berlebih dapat menginisiasi terjadinya lipid peroksidase. Pada studi terdahulu juga ditemukan bahwa kadar F2-isoprostan meningkat pada subyek sehat setelah melakukan pelatihan fisik berupa knee extensor selama tiga jam. ${ }^{18,19}$ Menururt Sacheck et al. $^{20}$ peningkatan kadar F2isoprostan dapat ditemukan 72 jam setelah pelatihan fisik ekstrem akibat kerusakan pada otot.

Hasil penelitian ini menunjukkan bahwa pemberiaan ekstrak daun Gandarusa berpotensi untuk menurunkan kadar f2isoprostan pada pelatihan fisik berlebih. Didukung oleh hasil analisis efek perlakuan yang menunjukkan bahwa pada kelompok 
perlakuan (P1) terjadi penurunan kadar F2isoprostan yang bermakna dari $5,46 \pm 0,655$ $\mathrm{ng} / \mathrm{mL}$ menjadi $3,61 \pm 0,389$ setelah 4 minggu diberikan perlakuan berupa pelatihan fisik berlebih dan ekstrak daun gandarusa $(P<0,01)$. Hasil penelitian ini tidak terlepas dari kandungan senyawa bioaktif di dalam ekstrak daun gandarusa. Analisis fitokimia yang dilakukan di Laboratorium Teknologi Pertanian Universitas Udayana (2016) menunjukkan bahwa ekstrak air daun gandarusa (Justicia gendarussa Burm. f.) mengandung flavonoid dengan kadar total fenol 214,55 $\mathrm{mg} / 100 \mathrm{gQE}$, tannin $128,09 \mathrm{mg} / 100 \mathrm{gQE}$, saponin $48,93 \mathrm{mg} / 100 \mathrm{gQE}$, dengan aktivitas antioksidan sebesar 257,26 ppm GAEAC dan inhibition concentration 50 (IC50) sebesar $4,15 \mathrm{mg} / \mathrm{ml}$.

Polifenol dan flavonoid mempunyai peran penting sebagai antioksidan pada tanaman. $^{21}$ Kedua senyawa ini bertindak sebagai penangkap oksigen (oxygen scavenger) dan gugus hidroksil yang tinggi di dalam struktur fenolid akan meningkatkan aktivitas antioksidannya. ${ }^{22}$

Flavonoid merupakan salah satu senyawa yang memiliki aktivitas antioksidan tinggi Analisis fitokimia menunjukkan kandungan flavonoid pada ekstrak air daun gandarusa (Justicia gendarussa Burm. f.) yang digunakan dalam penelitian ini cukup besar yaitu $64,88 \mathrm{mg} / 100 \mathrm{gQE}$. Efek flavonoid terhadap ROS terjadi melalui dua mekanisme yaitu dengan meningkatkan antioksidan endogen dan menangkap radikal bebas/menetralisir. Peningkatan antioksidan endogen oleh flavonoid telah terbukti dalam penelitian in vitro melalui peningkatan faktor transkripsi Nrf2 yang meningkatkan ekspresi protein HO1. ${ }^{23}$ Flavonoid dapat mengaktifkan ERK, JNK, dan P38 yang selanjutnya mengaktifkan Nrf2 sehingga terjadi peningkatan ekspresi gen antioksidan endogen. $^{24}$

Dalam kaitannya dengan menetralisir radikal bebas, flavonoid dapat menghambat peroksidasi lipid melalui aktivasi peroksidase terhadap hemoglobin, yang merupakan antioksidan endogen (enzimatis). ${ }^{25}$ Peroksidase bermanfaat untuk mencegah penimbunan $\mathrm{H}_{2} \mathrm{O}_{2}$, yang keberadaannya menjadi berbahaya jika diikuti dengan peningkatan kadar $\mathrm{O} 2 \bullet-$, dikarenakan dapat membentuk radikal $\bullet \mathrm{OH}$ yang merupakan radikal bebas yang paling reaktif dan paling berbahaya, yang dapat merusak membran sel dengan menyebabkan terputusnya asam lemak tidak jenuh. ${ }^{26}$ Selain itu kandungan flavonoid juga diketahui merupakan antioksidan pemutus rantai (chain breaking antioxidant) yang larut dalam lemak dan bekerja pada membran sel sehingga dapat memutuskan rantai peroksidasi lipid. ${ }^{27,28}$

Mekanisme antioksidan ekstrak daun gandarusa dalam mencegah kerusakan oksidatif akibat pelatihan fisik berlebih ialah karena kemampuannya untuk menstabilkan membran sel. Membran sel yang stabil dibutuhkan oleh lisosom untuk mencegah pelepasan respon inflamasi, dimana inflamasi dapat memicu pembentukan ROS. ${ }^{13}$ F2isoprostan yang terlibat dalam inflamasi akut maupun inflamasi kronik, dengan PGF $2 \alpha$ sebagai perantara terjadinya inflamasi akibat radikal bebas yang kemudian menginisiasi stres oksidatif ${ }^{14}$ sehingga pemberian eksktrak daun gandarusa dapat menurunkan kadar F2isoprostan yang meningkat akibat induksi pelatihan fisik berlebih.

\section{SIMPULAN}

Berdasarkan hasil penelitian ini dapat disimpulkan bahwa pemberian ekstrak daun gandarusa (Justicia gendarussa Burm. f.) dapat menurunkan kadar F2-isoprostan urin tikus wistar jantan yang diinduksi pelatihan fisik berlebih.

\section{DAFTAR PUSTAKA}

1. Hatfield FC. Overreaching and Overtraining. International Sport Sciences Association. 2001:1-11. Available from: www.timinvermont.com

2. Urhausen A, Kindermann W. Diagnosis of overtraining: what tools do we have? Sports Med. 2002;32(2): 95-102.

3. Woods JA, Wilund KR, Martin SA, Kistler BM. Exercise, inflammation and aging. Aging Dis. 2012;3(1):130-40. 
4. Bagiada NA. Proses Penuaan dan Penanggulangannya. Denpasar: Fakultas Kedokteran Universitas Udayana; 2001; p. 22 .

5. Baynes JW, Dominiczak MH. 2014. Oxygen and life (Chapter 37). Medical Biochemistry (4th ed). Elsevier online access, 2014; p. 486-95.

6. Hajjouli S. Eurycomanone and eurycomanol from Eurycoma longifolia jack as regulators of signaling pathways involved in proliferation, cell death and inflammation. Molecules. 2014;(19): 14649-66.

7. Hanak D. 2010. Isoprostane lipid peroxidation. [cited 2016 Sept 4]. Available from http://www. kronoslaboratory.com/dotnetnuke/Fea turedAssays/Isoprostanes/ tabid/130/Default.aspx.

8. Morrow JS, Zackert WE, Van der Ende DS, Reich EE, Terry ES, Cox B. Quantification of isoprostanes as indicators of oxidant stress in vivo. In: Cadenas E, Dekker LP, editors, Handbook of Antioxidant. New York: Marcel Dekker, Inc, 2002; p.57-71.

9. Rahman K. 2007. Studies on free radicals, anioxidants, and co-factors. Clinical Interventions in Aging. School of Biomolecular Sciences. Liverpool. 2(2) 219-236.

10. Mau JL, Chao GR, Wu KT. Antioxidant properties of methanolic extracts from several ear mushroom. J Agric Food Chem. 2001;(49):5461-7.

11. Gulcin I, Oktay M, Kufrevioglu OI, Asian A. Determinations of antioxidant activity of lichen Cetraria islandica (L) Ach. J Ethnopharmacol. 2002;(79): 325-329.

12. Katrin, Elya B, Amin J, Permawati M. Aktivitas Ekstrak air daun gandarusa (Justicia gendarusa Burm.f) terhadap penurunan kadar asam urat darah tikus. Jurnal Bahan Alam Indonesia. 2009;7(1):24-8.

13. Varghese CP, Ambrose C, Jin SC, Lim YJ, Keisaban T. Antioxidant and anti-inflammatory activity of Eurycoma longifolia Jack. A traditional medicinal plant in Malaysia. Int J Pharm Sci Nanotechnol. 2013;5(4):1875-8.

14. Basu S. Comprehensive invited review: F2- isoprostane in human health and diseases: From molecular mechanism to clinical implications. Antioxid Redox Signal. 2008;10(8):1405-34.

15. Sauza TP, Oliveira PR, Pereira B. Physical exercise and oxidative stress, effect on intense physical exercise on urinary chemiluminescence and plasmatic malondialdehyde. Rev Bras Med Esporte. 2005;11(1) Jan/Fev.

16. Baraas F. Kardiomolekuler, Radikal Bebas, Disfungsi Endotel, Aterosklerosis, Antioksidan, Latihan Fisik dan Rehabilitasi Jantung. Jakarta: Yayasan Kardia Ikratama, 2006; p. 266-95

17. McArdle WD. Essentials of Exercise Physiology (3rd ed). NewYork: Lippincott William Wilkins, 2006; p. 642.

18. Fischer CP, Hiscock NJ, Penkowa M, Basu S, Vessby B, Kallner A, et al. Supplementation with vitamins $\mathrm{C}$ and $\mathrm{E}$ inhibits the release of interleukin-6 from contracting human skeletal muscle. J Physiol. 2004;558:633-45.

19. Fischer CP, Hiscock NJ, Basu S, Vessby B, Kallner A, Sjoberg LB, et al. Vitamin E isoform-specific inhibition of the exercise-induced heat shock protein 72 expression in humans. J Appl Physiol. 2006;100: 1679-87.

20. Sacheck JM, Milbury PE, Cannon JG, Roubenoff R, Blumberg JB. Effect of vitamin $\mathrm{E}$ and eccentric exercise on selected biomarkers of oxidative stress in young and elderly men. Free Radic Biol Med. 2003;34(12):1575-88.

21. Wu LC, Hsu HW, Chen YC, Chiu CC, Lin YI, Ho JA. Antioxidant and antiproliferative activities of red pitaya. Food Chem. 2006;95:319-27.

22. Llorach R, Ascension MS, Francisco ATB, Maria IG, Federico F. Characterization of polyphenols and antioxidant properties of five lettuce varieties and escarole. J Food Chem. 2007;108(3):1028-38.

23. Maher P, Hanneken A. Flavonoids protect retinal ganglion cells from oxidative stress-induced death. Invest Ophthalmol Vis Sci. 2005;46(12):4796803

24. Huang CS, Lii CK, Lin AH, Yeh YW, Yao HT, Li CC, et al. Protection by chrysin, apigenin, and luteolin against 
oxidative stress is mediated by the Nrf2-dependent up-regulation of heme oxygenase 1 and glutamate cysteine ligase in rat primary hepatocytes. Arch Toxicol. 2013;87:167-78.

25. Mot AC, Damian G, Sarbu C, Silaghi DR. Redox reactivity in propolis: direct detection of free radicals in basic medium and interaction with hemoglobin. J Med Food. 2009;14(6): 267-74

26. Cadenas E, Jones PD. Bioavailability of glutathione. In: Cadenas E, Packer L, editors. Handbook of Antioxidants (2nd ed). New York: Marcel Dekker, Inc, 2002; p. 549-64.
27. Murray RK, Rodwell VW, Bender D, Botham KM, Weil A, Kennelly PJ. Harper's Illustrated Biochemistry (28th ed). USA: Mc Graw Hill, 2009; p.101.

28. Milner JA. 2000. Mechanism of action of antioxidant: A substance in food that significantly decrease the adverse effects of reactive species such as reactive oxygen and nitrogen species, on normal physiologycal funtion in human. Dietary Reference Intake, Foods and Nutrition. Natl Acad Press. [cited 2017 Jan 23]. Available from: http//ods.od.nih.gov/nems/ conference/oda2002/milner-pdf . 